\title{
MOTIF DAN NILAI DI BALIK PRAKTIK BEREBUT JENAZAH DI TORAJA
}

\section{The Motives And The Values Behind The Practice of Competing Body In Toraja}

\author{
Abraham Sere Tanggulungan \& Joni Tapingku \\ Sekolah Tinggi Agama Kristen Negeri Toraja \\ Jl. Poros Makale-Makassar Km. 11,5 Tana Toraja \\ Email: stakntoraja@yahoo.com
}

Naskah diterima tanggal 08 Maret 2015. Naskah direvisi tanggal 02 April 2015 Naskah disetujui tanggal 03 November 2015

\begin{abstract}
Abstrak
Penelitian ini didasari oleh adanya praktik berebut jenazah di Toraja. Praktik ini terlihat tidak masuk akal, mengingat konsekuensi pelaksanaan upacara kematian atau aluk rambu solo' dalam masyarakat Toraja yang berbiaya tinggi. Mengingat hal itu, maka tujuan penelitian ini adalah untuk mengungkapkan motif dan nilai yang mendasari praktik tersebut. Dengan menggunakan pendekatan penelitian kualitatif, dan menetapkan Kecamatan Tondon, Kabupaten Toraja Utara, sebagai lokus penelitian, maka diperoleh kesimpulan bahwa motif yang melatari praktik berebut jenazah ialah motif cinta kasih, mebala kollong, egoisme dan ekonomi. Mendalam di balik motif itu terdapat nilai-nilai seperti nilai religius, kekeluargaan, persekutuan, longko' atau siri', dan nilai pragmatisme-materialistis. Temuan ini menunjukkan bahwa motif dan nilai yang mendasari praktik tersebut ada yang luhur dan sesuai dengan nilai-nilai keagamaan (Kristiani) tetapi ada pula yang bertentangan.
\end{abstract}

Kata kunci: Toraja, Kristen, jenazah, nilai

\begin{abstract}
This research was based on the existence of the competition among families in Toraja to take over their families' bodies. These practices seemed to be illogical by taking into account the consequences of the implementation of costly funeral ceremony or aluk rambu solo' in Torajanese society. Therefore, the objective of the research was to reveal the motives and values that underlie these practices. By using a qualitative research approach and by determining Tondon subdistrict in North Toraja Regency as the locus of research, it could be concluded that the motives of competing to take over the bodies were love, mebala kollong ( $a$ kind of affectation/lip service), egoism and economic motives. The profound motives behind those practices were some values such as religious, kinship, fellowship, longko' or siri, and pragmatism-materialistic values. These findings indicate that the motives and values that underlie the existence of these practices are partially sincere and in accordance with the (Christian) religious values, but some are contradictory.
\end{abstract}

Keywords: Toraja, Christian, bodies, value.

\section{PENDAHULUAN}

$\mathrm{P}$ ada hari Minggu, 6 April 2014, seorang anak kecil tercebur ke kolam, tepatnya sebuah kubangan yang digali tukang bangunan di sebelah rumah yang baru seminggu dikontrak oleh orang tuanya. Kejadian yang diperkirakan terjadi pada pukul 14.00 wita tersebut menyebabkan nyawa anak kecil berumur 2,5 tahun tersebut tidak tertolong. Anak tersebut meninggal walau masih sempat dibawa ke Rumah Sakit. Sekembalinya ke rumah, jenazah anak tersebut dilanjutkan ke kampung asal orang tuanya, yakni Tondon Langi', Kecamatan Tondon setelah diadakan pemotongan hewan di rumah kontrakan tersebut.

Yang menarik, ketika tiba di Tondon, jenazah anak kecil tersebut dibawa oleh kerabatnya yang lain ke rumah adat (Tongkonan) lain. Rumah Tongkonan tersebut diperkirakan berjarak sekitar 200 meter dari rumah Tongkonan kakek dan nenek yang meninggal, yakni rumah Tongkonan yang semula direncanakan sebagai tempat pesemayaman 
jenazah tersebut. Suasana menjadi semakin kacau setelah tangis histeris ibu korban. Keluarga yang sudah datang melayat juga mulai mengeluarkan kata-kata penyesalan atas sikap keluarga yang menyerobot jenazah tersebut. Saling tuding dan saling mempersalahkan antar keluarga kian merebak. Kata-kata yang penuh dengan amarah nyaris tak terkendali lagi.

Apa yang terjadi pada hari Minggu, 6 April 2014 tersebut, hanyalah salah satu dari sekian kasus yang pernah atau kerapkali terjadi di Toraja. Dalam berbagai bentuk lainnya, perebutan, penyerobotan, atau pencurian jenazah, juga beberapa kali terjadi. Pihak-pihak yang terlibat tentu bukan tanpa hubungan kekeluargaan sama sekali. Bentuk yang paling lazim muncul dalam wujud alotnya pembicaraan keluarga si mati dalam menentukan tempat di mana jenazah akan diupacarakan kelak. Uniknya, mereka yang berebut itu selalu berasal dari rumpun keluarga yang bertali-temali secara cukup dekat, dan kejadian seperti itu khas terjadi di Toraja.

Memperhatikan upacara pemakaman orang Toraja yang menelan biaya mahal, maka pemenang perebutan jenazah justru menanggung beban ekonomi yang tidak ringan. Semakin kaya dan berkuasa seseorang, maka biaya upacara pemakamannya akan semakin mahal pula. Dalam alukta (agama nenek moyang orang Toraja), hanya keluarga bangsawan yang berhak menggelar pesta pemakaman yang besar. Pesta pemakaman seorang bangsawan biasanya dihadiri oleh ratusan orang dan berlangsung selama beberapa hari. Namun seiring dengan modernitas, kekayaan pada gilirannya menjadi satu-satunya tolok ukur besarnya upacara pemakaman. Pada sisi lain, secara psikologi sosial, gengsi keluarga menggiring mereka untuk melampaui kemampuan ekonomi mereka untuk mengadakan upacara pemakaman yang besar.

Mengingat mahalnya biaya pemakaman, maka perebutan jenazah tampak merupakan suatu ironi; sebuah tindakan yang tampak out of logic. Banyak pertanyaan yang bisa dimunculkan terhadap kejadian-kejadian tersebut di atas. Namun, pertanyaan yang spontan dapat dikemukakan adalah, mengapa hal tersebut terjadi? Apa motivasi di balik perebutan jenazah seperti itu? Inilah misteri yang hendak dikaji dalam penelitian ini.

Kasus perebutan jenazah terjadi di hampir semua wilayah adat di Toraja. Dari 32 wilayah adat Toraja yang ada, mungkin tak satupun yang tidak pernah mengalami kejadian serupa. Perbedaan wilayah adat mungkin saja menjadi salah satu faktor pembeda satu dengan yang lainnya. Oleh karena itu, penelitian ini difokuskan pada wilayah adat Tondon, Kecamatan Tondon, Kabupaten Toraja Utara.

\section{METODE PENELITIAN}

Artikel ini merupakan hasil penelitian deskriptif kualitatif yang berkenaan dengan motivasi berebut jenazah di wilayah Kecamatan Tondon, Kabupaten Toraja Utara. Sumber penelitian ini bersumber dari data lapangan dan data kepustakaan. Data kepustakaan bersifat sekunder, sementara data yang diperoleh dari lapangan bersifat primer.

Pengumpulan data kepustakaan dilakukan dengan mencari berbagai literatur yang berkaitan dengan topik kajian, terutama yang berhubungan langsung dengan data lapangan. Sedangkan pengumpulan data lapangan dilakukan dengan tekhnik observasi dan wawancara. Tekhnik observasi dilakukan untuk mengumpulkan data lapangan dengan mengadakan pengamatan langsung di lapangan dan survei secara sistematik untuk melakukan kegiatan perekaman data. Tekhnik wawancara dilakukan untuk mengumpulkan data oral (tradisi lisan) yang tidak dapat diamati secara langsung. Instrumen yang digunakan dalam tekhnik wawancara ialah pedoman wawancara berupa daftar pertanyaan pokok yang merupakan acuan pelaksanaan wawancara.

Analisis deskriptif kualitatif dilakukan dengan tiga langkah, yakni reduksi, display dan interpretasi data. Dalam praktiknya, ketiga komponen analisis ini berjalan secara simultan. Langkah awal merupakan tahapan mengklasifikasi data ke dalam kategorikategori besar sesuai dengan hasil pengumpulan data. Data ini dipaparkan sebagaimana adanya, dan diinterpretasi untuk menarik makna yang terkandung di dalamnya sesuai konteks dan ruang penelitian.

\section{PEMBAHASAN \\ Deskripsi Kasus}

Berebut jenazah hampir tidak pernah alpa dalam percakapan di sekitar perlakuan terhadap orang meninggal. Perebutan itu berada pada skala kecil dan besar, biasa maupun ekstrim. Berikut ini dipaparkan tiga contoh kasus berebut jenazah pada skala besar dan ekstrim yang pernah terjadi di Kecamatan Tondon, Kabupaten Toraja Utara.

\section{Kasus pertama}

Kasus pertama telah dipaparkan sebagian pada bagian pendahuluan, yakni kasus anak yang mati tercebur di kubangan. Ibu korban berasal 
dari daerah Mengkendek, Kabupaten Tana Toraja. Sedangkan ayahnya berasal dari Kecamatan Tondon, Kabupaten Toraja Utara. Perebutan jenazah tidak terjadi antara ayah dan ibu korban yang berasal dari wilayah adat yang berbeda. Walau ada kerinduan dari pihak keluarga ibu korban untuk membawa jenazah ke Mengkendek, namun sang ibu tidak terlalu berkeras hati. Kedua orang tua korban lebih berpikir praktis bahwa Tondon lebih dekat dari tempat tinggal mereka di mana terjadi kejadian yang menyebabkan kematian sang anak.

Jenazah dibawa ke Tondon, namun sesampainya di Tondon, jenazah diperebutkan oleh pihak keluarga batihnya dengan pihak keluarga besarnya. Pada akhirnya, jenazah diserahkan kepada pihak keluarga batih setelah diinapkan semalam di rumah keluarga besar dan kepadanya dilakukan beberapa ritual upacara kecil. Walau akhirnya jenazah diserahkan kepada pihak keluarga batih, namun prosesnya cukup berbelit serta menguras waktu dan pikiran orang-orang yang terlibat langsung dalam kejadian.

\section{Kasus kedua}

Kasus kedua berhubungan dengan kematian seorang ibu muda. Alamarhumah meninggal di Rumah Sakit di Rantepao setelah dirawat beberapa hari karena sakit. Suaminya berasal dari Kollo, sebuah daerah dalam wilayah Lembang Tondon Siba'ta, Kecamatan Tondon. Sebelum menikah, almarhumah tinggal bersama orang tuanya di Lembang Tondon Langi', Kecamatan Tondon. Namun sejak menikah, almarhumah mengikuti suaminya tinggal di Kollo. Ibu almarhumah sendiri berasal dari Tondon Langi, sedangkan ayahnya berasal dari daerah asal suaminya, yakni Kollo. Dengan demikian, almarhumah memiliki banyak kerabat di Kollo dari pihak ayahnya.

Sebelum jenazah dibawa keluar meninggalkan Rumah Sakit, terjadilah insiden pertengkaran memperebutkan jenazah. Suaminya dan kerabat keluarga ayahnya dari Kollo menghendaki jenazah dibawa ke Kollo. Pada pihak lain, ibu dan saudarasaudara almarhumah serta kerabat keluarga yang lain yang berasal dari Tondon Langi', memaksa membawa jenazah ke Tondon Langi'. Menurut beberapa informan, perebutan tersebut sangat sengit, penuh pertengkaran, bahkan nyaris mengakibatkan perkelahian antara kedua belah pihak. Bahkan ada yang sangat emosional meminta supaya jenazah dipotong menjadi dua bagian supaya masing-masing pihak membawa jenazah ke tempat masing-masing.
Setelah melalui perdebatan panjang, akhirnya jenazah dibawa ke Tondon Langi'. Masing-masing pihak, khususnya pihak keluarga dari Kollo, mengalah setelah ayah almarhumah memutuskan membawa jenazah anaknya ke Tondon Langi'. Perlu digaris bawahi bahwa ayah almarhumah berasal dari Kollo, tetapi sejak menikah sang ayath tinggal di Tondon Langi'. Dengan demikian, ayah almarhumah sudah bertahun-tahun berdomisili di Tondon Langi.

\section{Kasus ketiga}

Kasus ketiga adalah kasus perebutan jenazah seorang nenek. Semasa hidupnya, almarhumah menikah sebanyak dua kali. Kedua suaminya berasal dari Tondon Langi, dan keduanya pun telah meninggal dunia. Almarhumah memiliki lima orang anak: seorang anak dari pernikahan pertama dan empat orang anak dari pernikahan kedua. Almarhumah mencapai umur sepuh. Bahkan beberapa anaknya juga sudah memiliki cucu. Selama masa tuanya, almarhumah tinggal berpindah-pindah dari rumah anaknya yang satu ke rumah anaknya yang lain. Akhirnya, almarhumah meninggal di rumah anaknya yang tinggal di sebuah rumah Tongkonan (rumah adat Toraja).

Menjelang upacara penguburan, anak-anak almarhumah mengadakan rapat, namun tidak menemui kata sepakat soal di mana dan bagaimana bentuk upacara penguburan. Salah seorang anak almarhumah berkeras hati mengupacarakan ibunya di rumah Tongkonan yang ditinggalinya. Semua saudara-saudaranya setuju, kecuali kakak tertua yang berasal dari ayah yang lain. Kakak tertua juga menghendaki supaya ibunya dibawa dan diupacarakan di rumah Tongkonan-nya.

Karena tidak ada kata sepakat, akhirnya almarhumah diupacarakan sebanyak dua kali. Upacara pertama dilaksanakan di rumah di mana almarhumah meninggal, sedangkan upacara kedua dilaksanakan di rumah anak almarhumah yang tertua.

\section{Motif Berebut Jenazah \\ Kecintaan kepada orang meninggal}

Kecintaan kepada orang yang meninggal merupakan salah satu pendorong utama tradisi berebut jenazah di kalangan masyarakat Kecamatan Tondon Langi. Mereka yang terlibat dalam praktik berebut jenazah merasa amat kehilangan dengan kematian anggota keluarganya. Karena itu, selalu ada keinginan untuk mendekatkan diri dengan 
orang yang meninggal, walaupun itu tinggal jenazah saja. Keluarga yang ditinggal tidak siap menerima kenyataan terpisah dari orang yang meninggal.

\section{Mebala Kollong}

Mebala kollong adalah ungkapan Toraja yang bermakna ungkapan basa-basi. Penutur tidak bersungguh-sungguh dengan apa yang dituturkannya. Oleh sebab itu, bila mebala kollong bersifat permintaan seperti yang lazim dalam berebut jenazah, maka pengabulan permintaan itu tidak selalu dikehendaki oleh pemohon.

Mebala kollong dalam tradisi berebut jenazah di Tondon Langi' pada khususnya, dan bahkan di Toraja pada umumnya, hampir selalu terjadi ketika berhadapan dengan penentuan tempat di mana jenazah akan diupacarakan. To dileso didalukki' (rumpun keluarga besar) adalah alasan yang mendasari motif mebala kollong. Status dileso didaluk menempatkan orang yang meninggal sebagai bagian dari sebuah rumpun keluarga yang besar. Orang yang meninggal adalah milik dari banyak orang, yaitu mereka yang bertalian darah dengannya. Atas dasar hubungan darah itulah, banyak orang yang merasa memiliki hak untuk memiliki orang yang meninggal.

Mereka yang mebala kollong biasanya adalah pihak keluarga yang sesungguhnya menyadari bahwa mereka tidak lebih berhak dari pada keluarga yang lain. Mereka mebala kollong sekedar untuk menunjukkan bahwa mereka pun merindukan dan berhak memiliki orang yang meninggal.

\section{Egoisme}

Jika mebala kollong adalah permintaan yang tidak sungguh-sungguh untuk memiliki jenazah, maka ada pula permintaan yang sangat bersungguh-sungguh. Pada posisi ketika semua pihak bersungguh-sungguh merasa berhak atas orang yang meninggal, pada kondisi inilah sering terjadi perebutan jenazah karena dorongan egoisme.

Kasus kedua dan ketiga di atas adalah cerminan dari perebutan jenazah jenis ini. Pada kasus kedua, baik suami maupun orang tua yang meninggal merasa bahwa merekalah yang paling berhak memilik jenazah almarhumah. Pada kasus ketiga, baik anak tertua maupun keempat adiknya sama-sama memiliki klaim kuat kepemilikan jenazah ibu mereka. Di sekitar kedua pihak yang berebut dengan sungguh-sungguh itu, dipastikan ada pihak lain yang sekadar mebala kollong.

\section{Ekonomi}

Motif ekonomi berhubungan dengan perhitungan untung rugi yang akan dialami sebagai konsekuensi pelaksanaan pemakaman jenazah. Hal ini paling menonjol dalam kasus ketiga. Keempat bersaudara sadar benar konsekuensi yang akan terjadi apabila mengikuti kemauan kakak tertua mereka. Ada dua konsekuensi yang akan terjadi. Pertama, kakak tertua bertempat tinggal di rumah Tongkonan yang berbeda dengan rumah Tongkonan adik-adiknya di mana jenazah disemayamkan untuk sementara. Antara kedua rumah Tongkonan itu, ada perbedaan status sosial. Bilamana dilaksanakan di rumah Tongkonan kakak tertua, maka level upacara akan naik. Kenaikan level upacara tersebut akan berbanding lurus dengan besarnya hewan yang akan dipotong. Hal itu berarti, biaya pemakaman akan bertambah besar pula. Kedua, pemindahan jenazah sebagaimana bila pelaksanaan upacara telah tiba, selalu melibatkan orang dalam jumlah besar. Pelibatan orang dalam jumlah besar tentu menuntut pengorbanan yang besar pula. Hal ini berhubungan dengan biaya transportasi pemindahan jenazah, biaya makan, biaya minum, biaya pembelian rokok, dan sebagainya.

Di Kecamatan Tondon pada umumnya, upacara pemindahan jenazah saja kadang kala sudah ada pembagian daging hewan, khususnya babi. Ini merupakan bagian dari adat yang dikontemporerkan, yang sesungguhnya bermotif ekonomi belaka. Para ambe' tondok (pemangku adat) mempolitisasi hal ini untuk mendapatkan keuntungan materil dari keluarga yang berhajatan.

\section{Nilai Berebut Jenazah}

Motif dan nilai adalah dua hal yang sesungguhnya tidak dapat dipisahkan secara tajam. Di balik motif terdapat nilai yang mendasarinya. Sebaliknya, nilai yang dianut merupakan titik pangkal suatu aktivitas.

Nilai pada dasarnya bermakna sesuatu yang dijunjung tinggi seseorang, sebagai yang sangat bermakna atau penting. Nanda dan Warms menyebut: values are shared ideas about what is true, right, and beautiful (Nanda and Warms, 2012:35). Nilai dapat bersifat personal namun bisa juga bersifat komunal. Kedua spektrum nilai inilah yang sering berada dalam ketegangan dinamis. Namun pada gilirannya, nilai sosiallah yang pada umumnya lebih dominan. Hal ini mengingat sifat dasar manusia sebagai makhluk sosial yang cenderung conform dengan sosialitasnya. 
Pada dasarnya aluk rambu solo' (upacara pemakaman) adalah penampakan dari suatu konfigurasi nilai-nilai dasar yang menentukan pola hidup orang Toraja (PUSBANG Gereja Toraja, 1996:120-132). Berdasarkan hasil penelitian, dapat dikemukakan enam nilai yang mendasari praktik berebut jenazah di Kecamatan Tondon, Kabupaten Toraja Utara.

\section{Nilai religius}

Pada kasus pertama, salah satu penyebab perebutan itu ialah adanya keterikatan pada sesuatu yang dianggap tabu. Keluarga di rumah Tongkonan tua, yakni tempat di mana jenazah pertama-tama disemayamkan, berkeberatan bilamana jenazah diambil begitu saja tanpa sebuah penumpahan darah hewan. Keluarga takut terjadi malapetaka di kemudian hari akibat melanggar aluk to mate (upacara memuja orang mati) dan aluk banua (upacara memuja rumah) yang berkelindan dalam situasi tersebut. Menghindari terjadinya malapetaka di kemudian hari, maka pada waktu malam, sekitar pukul 21.00 wita, dipotonglah seekor babi. Alasan kebutuhan makan malam saat itu tidak lebih penting daripada ketakutan melanggar pemali atas aluk banua. Dalam kepercayaan nenek moyang orang Toraja, di sekitar rumah Tongkonan tidak boleh dilakukan sesuatu yang tidak sejalan dengan tuntutan aluk karena rumah Tongkonan adalah pusat dari semua ritus-ritus.

Dalam kasus ketiga, nilai religius juga cukup kental. Kakak tertua sadar betul beratnya biaya yang akan ditanggungnya dengan mengupacarakan pemakaman ibunya di rumah Tongkonan yang ditinggalinya. Namun tetap rela melakukan itu demi memberi 'bekal' kepada ibunya yang sudah meninggal. Keyakinan tersebut adalah khas dalam alam pikiran penganut agama nenek moyang orang Toraja (alukta). Walaupun alukta tidak ada lagi di Kecamatan Tondon secara administratif, namun dalam prakteknya keyakinan itu masih hidup, setidaknya dalam diri kakak tertua, anak dari almarhumah dalam kasus ketiga di atas.

Kedua kasus tersebut (pertama dan ketiga) menguatkan sinyalemen mistisisme manusia Toraja. Manusia Toraja adalah makhluk mitis: dilahirkan ke dalam dunia ini, hidup secara pragmatis dalam ikatan aluk dan pemali untuk kembali ke alam mitis. Pelanggaran terhadap aluk dan pemali langsung mendapat hukuman dalam dunia ini, karena itu tidak boleh mengabaikan ritual aluk rambu solo'. Jika melalaikan, maka rohnya tertunda bahkan tidak masuk ke alam baka (Tim Institut Theologia, 1983:1).

\section{Nilai kekeluargaan}

Orang Toraja terkenal dengan ikatan kekeluargaan yang sangat kuat. Bagi orang Toraja, perebuatan jenazah adalah salah satu wujud dari ungkanana'i rara buku (menjaga hubungan kekeluargaan). Dalam setiap peristiwa kematian, semua yang memiliki pertalian darah, baik secara genealogis maupun melalui hubungan perkawinan, akan turut merasakan dukacita tersebut. Tidak ada keluarga yang menunggu undangan untuk datang bersungkawa. Anggota yang datang pun bukan hanya bersungkawa, tetapi juga berusaha untuk mengambil peran aktif di dalamnya. Bila tidak demikian, maka orang tersebut akan dianggap tidak peduli terhadap keluarga. Mereka akan dipandang sebagai keluarga yang tidak mempunyai rasa kasih sayang kepada keluarganya yang meninggal.

\section{Nilai persekutuan}

Nilai persekutuan adalah salah satu wujud sosialitas manusia Toraja. Ikatan sosial sangat kental membentuk kedirian seorang manusia Toraja. Nilai persekutuan dapat dipandang sebagai perluasan dan sisi lain dari nilai kekeluargaan pada aras yang lebih luas. Hal itu pun tercermin dalam praktik berebut jenazah.

Dalam kasus kedua di atas, persekutuan sosial orang Kollo sedang berhadapan dengan persekutuan sosial orang Tondon Langi'. Suami almarhumah mendapat dukungan dari sesamanya orang Kollo untuk mengklaim jenazah, sebaliknya orang tua almarhumah didukung oleh kerabat luas di Tondon Langi.

Prinsip resiprositas kelompok ada di balik perebutan jenazah. Kedua pihak yang berebut jenazah berada dan ingin bertindak memenuhi tuntutan sosial kelompoknya masing-masing. Salah satu kesempatan, bahkan yang terutama, di mana kewajiban membayar tuntutan sosial itu mendapat ruang, adalah dalam upacara rambu solo'. Di dalam upacara tersebut terjadi bentuk transaksi sosial yang bersifat resiprokal. Keluarga yang melakukan upacara berkewajiban melakukan pembagian daging kepada masyakat sebagaimana keluarga pun telah mendapat pembagian daging pada upacara yang sama sebelumnya.

Dalam kasus kedua, pihak keluarga suami almarhumah merasa jenazah harus diupacarakan di Kollo, karena selama ini almarhumah telah banyak menerima daging dari masyarakat Kollo. Baginya, 
upacara pemakaman jenazah istrinya adalah saat untuk membayar hutang. Tarik menarik kepentingan membayar hutang dan memberi piutang itulah yang memunculkan praktik berebut jenazah.

\section{Nilai longko' atau siri'}

Secara leksikal, longko' atau siri' berarti malu, segan (van der Veen, 1972:327, 558). Longko' Toraya adalah salah satu faktor pendorong utama berbagai tindakan sosial manusia Toraja. Ungkapan Apa la nakuangki' tau ('apa kata orang nantinya) adalah prinsip yang ada di balik praktik berebut jenazah. Orang yang mebala kollong, misalnya, pasti terdorong oleh nilai longko' tersebut.

Nilai longko' juga mengiringi keinginan menentukan tingkatan upacara aluk rambu solo'. Apa yang terjadi dalam kasus ketiga di atas tidak lepas pula dari longko' Toraya. Kakak tertua tidak sanggup menahan malu bilamana tidak mengupacarakan jenazah ibunya menurut level yang dipersepsikan orang-orang di sekitarnya. Sang kakak pun berkepentingan menunjukkan status Tongkonan-nya sebagai Tongkonan besar.

Secara umum dapat dikatakan bahwa longko' berjalan beriringan dengan asas hutang-piutang yang melekat pada upacara aluk rambu solo'.

\section{Nilai pragmatisme-materialisme}

Materialisme adalah salah satu nilai yang tidak dapat dimungkiri menyertai praktik berebut jenazah. Hal ini telah lama melekat pada budaya Toraja. Namun demikian, seiring dengan perjalanan waktu, roh materialisme kian berkembang liar dengan dukungan sikap pragmatis yang banyak mengisi ruang-ruang kebudayaan Toraja masa kini (Aditjondro, 2010:116).

Pada mulanya, ada satu bagian dari upacara aluk rambu solo' yang dikenal dengan nama mangrinding. Mangrinding adalah ritus pembagian harta kekayaan berdasarkan besarnya pengorbanan saat upacara pemakaman orang mati. Besarnya perolehan kekayaan berbanding lurus dengan besarnya pengorbanan hewan yang dilakukan seorang anak kepada orang tuanya. Hal ini mengkondisikan seorang anak berusaha seoptimal mungkin memberi kepada orang tuanya yang telah meninggal. Pada gilirannya, sikap ini rentan menimbulkan egoisme dan persaingan antar anak dari orang yang meninggal.

Apa yang terjadi pada kasus ketiga tidak lain dari adanya nilai pragmatis-materialis. Menurut beberapa orang di Tondon Langi', sikap kakak tertua yang bersikukuh membawa orang tuanya ke rumah Tongkonan-nya tidak lain daripada ekspresi kebelumsiapannya untuk mengupacarakan orang tuanya dalam waktu dekat. Sang kakak belum memiliki kerbau dalam jumlah yang cukup, baik untuk kepentingan mangrinding itu maupun untuk memenuhi level upacara yang diinginkannya. Di sini nampak jelas bahwa sang kakak ada dalam tarik ulur antara ketidaksiapan berupacara dengan kebutuhan pemenuhan gengsi dirinya dan Tongkonan-nya. Tentang faktor gengsi dalam hal semacam ini, Tino Sarungallo - membandingkan dengan yang terjadi di kalangan orang Manado mengatakan bahwa ajang persaingan gengsi terjadi dalam upacara-upacara adat. Upacara pemakaman di Tana Toraja misalnya, sudah terkontaminasi kesakralannya dengan kepentingan gengsi pribadi maupun keluarga besar (Sarungallo, 2008:113-114).

Sikap sang kakak jelas bertentangan dengan sikap adik-adiknya. Secara matematis-ekonomis, adik-adiknya cenderung realistis. Mereka lebih memilih untuk memberi sesuai kemampuan mereka daripada memaksa diri. Mereka tahu bahwa apa yang akan mereka peroleh tidak akan sebanding dengan apa yang akan mereka korbankan dalam upacara pemakaman orang tua mereka.

Yang menarik ialah kehadiran pihak ketiga, yaitu saroan (kelompok penghuni kampung yang berdekatan). Mereka ini banyak memainkan peran tersembunyi di balik perebutan jenazah. Mereka berkepentingan mendorong peningkatan level upacara menjadi lebih tinggi guna mendapatkan bahagian yang besar pula dari upacara tersebut. Mereka juga berperan menggiring pemindahan jenazah ke wilayah saroan-nya supaya mereka dapat terlibat dan berada dalam arena upacara secara determinan.

Permainan kelompok saroan tersebut bukan tidak disadari oleh pihak keluarga yang hendak melaksanakan upacara pemakaman, namun mereka seakan tidak berdaya menghadapinya. Hal ini sudah menjadi fakta sosial yang sulit dielakkan. Selain ada semacam fatalisme di dalamnya, tetapi juga ada dendam sosial. Pihak keluarga yang berduka tahu bahwa kelak akan tiba masanya pada upacara yang digelar oleh pihak lain, maka mereka pun akan menerima kembali apa yang dikorbankan itu dalam jumlah yang lebih besar.

Akumulasi nilai kekeluargaan dan persekutuan yang telah kehilangan dasar, yakni kepercayaan alukta dan yang ditunggangi oleh longko' telah melahirkan pragmatisme-materialisme yang tak terkontrol. Aditjondro mensinyalir kemunculan hal tersebut sebagai akibat adanya penghormatan yang 
tanpa kritik terhadap kekayaan dan kekuasaan yang dipicu oleh apresiasi dan rasa segan orang Toraja terhadap orang besar (to kapua) dan orang kaya (to sugi') (Aditjondro, 2010:138-144).

\section{Refleksi Teologis}

Alkitab, baik Perjanjian Lama maupun Perjanjian Baru tidak menjelaskan boleh atau tidak boleh memperebutkan jenazah. Alkitab, khususnya Perjanjian Lama hanya menjelaskan tentang upacara penguburan jenazah. Namun tidak berarti bahwa budaya Toraja yang sering memperebutkan jenazah pada upacara penguburan tidak dapat dinilai secara teologis.

Ungkapan "Ia mati pada waktu telah putih rambutnya, tua dan suntuk umur, maka ia dikumpulkan kepada kaum leluhurnya" (Kej. 25:8) merujuk kepada kekekalan perdamaian (Kidner, 1967:150; Keil and Kelitzsch, 1953:263; Allen, 1969:207). Abraham dikubur di gua Makhpela, yang dahulu telah dibeli dari bani Het, oleh kedua anaknya, Ishak dan Ismael, yang menandakan bahwa telah terjadi perdamaian di antara keduanya (Davis, 2001:248).

Makna perdamaian dari upacara penguburan juga ditunjukkan oleh Esau dan Yakub ketika menguburkan Ishak, ayah mereka (Kej. 35:22b-29). Menurut Davies, kenyataan bahwa Esau membantu Yakub menguburkan ayah mereka menunjukkan kerukunan dan perdamaian selanjutnya antara Esau dan Yakub (Davis, 2001:279).

Makna lain dari penguburan jenazah dalam Perjanjian Lama adalah sebagai bukti kasih dan kesetiaan kepada yang meninggal. Sebagai bukti kasih dan kesetiaan, Yusuf tidak menguburkan Yakub, ayahnya, di Mesir, melainkan di Kanaan, tanah airnya (Kej. 49:29).

Permintaan Yakub sebelum meninggal adalah supaya dirinya dikuburkan bersama nenek moyangnya di Kanaan. Yakub bersumpah (bnd. Kej. 24:2) bahwa dirinya akan memenuhi permintaan itu. Hal itu menunjukkan betapa penting permintaan Yakub itu. Dikubur dalam makam keluarga, bukan hanya tanda akhir hidup yang diharapkan, tetapi juga menandakan ikatan dengan para leluhurnya. Selain itu, dikubur di Kanaan berarti tanda bahwa dirinya memiliki tanah itu dan mengantisipasi hari kepulangan keturunannya dari Mesir (Bergant dan Karris, 2002:77).

Yang menarik ialah penghormatan Daud terhadap tulang-tulang Saul dan keturunannya (2 Sam. 21:12-14). Menurut Liem Thin Ping, tulangtulang orang yang meninggal melambangkan orang itu pernah ada (Kej. 2:23); bukti adanya janji Tuhan di dalam orang itu (Kej. 49:31, 32); orang itu melakukan sesuatu dalam diri anak cucu dan cicitnya (Mzm. 37:25); kuasa Allah ada dalam diri orang itu (2 Raj. 13:21); orang itu menjadi panutan banyak orang (Kej. 25:8-10); dan mampu memberi kehidupan bagi orang yang hidup (Yesus) (Thin Ping, 'Kuasa dari Tulang' dalam houseofallnations. blogspot.com.).

Dengan demikian, sekalipun Alkitab tidak menjelaskan tradisi boleh atau tidak boleh memperebutkan jenazah, namun Alkitab sendiri menjelaskan nilai-nilai teologis di balik penguburan jenazah di kuburan yang telah ditetapkan oleh keluarga.

\section{PENUTUP}

Berdasarkan hasil penelitian dan pembahasan yang telah diuraikan mengenai motif dan nilai praktik berebut jenazah, maka kesimpulan yang dapat ditarik adalah bahwa tradisi berebut jenazah sarat dengan motif dan nilai-nilai ke-Toraja-an. Pada pokoknya motif tersebut ada yang bersifat intrinsik dan ada yang bersifat ekstrinsik. Motif instrinsik berhubungan dengan dorongan yang berasal dari dalam diri keluarga si mati sendiri, sedangkan motif ekstrinsik berupa dorongan atau desakan yang berasal dari luar diri keluarga si mati tetapi bersifat memaksa keluarga si mati untuk melakukannya. Kedua motif tersebut berkelindan menjadi satu, sehingga tidak dapat dipisahkan secara tajam. Motif-motif itu berupa motif religius, motif sosial, dan motif ekonomi.

Kedua motif tersebut didasari oleh penghayatan sejumlah nilai-nilai hidup ke-Torajaan, baik yang diwarisi dari nenek moyang orang toraja sendiri maupun yang lahir sebagai buah dari perjumpaan atau interaksi dengan budaya kontemporer. Nilai-nilai tersebut yakni nilai kasih sayang, penghormatan, nilai ekonomi, siri' atau harga diri.

Secara teologis, nilai-nilai yang terdapat dalam tradisi berebut jenazah tersebut banyak yang bersesuaian dan sejalan dengan iman Kristen, tetapi ada pula yang bertentangan dengannya.

\section{UCAPAN TERIMA KASIH}

Penelitian ini terlaksana berkat bantuan dan dukungan berbagai pihak. Peneliti mempersembahkan penghargaan dan terima kasih yang tulus kepada Ketua STAKN Toraja dan Kepala Pusat Penelitian dan Pengabdian Masyarakat (P3M) STAKN Toraja yang telah menunjuk penulis untuk 
melaksanakan kegiatan penelitian ini. Penghargaan dan terima kasih yang sama peneliti tujukan kepada tokoh-tokoh adat dan tokoh-tokoh agama se-Kecamatan Tondon yang sudah membantu dan bekerjasama dalam melaksanakan kegiatan penelitian ini.

\section{DAFTAR PUSTAKA}

Aditjondro, George J. 2010. Pragmatisme Menjadi To Sugi' dan To Kapua di Toraja. Yogyakarta: Gunung Sopai.

Bergant, Dianne dan Robert J. Karris (eds.). 2002. Tafsir Alkitab Perjanjian Lama. Yogyakarta: Kanisius.

Davis, John J. 2001. Eksposisi Kitab Kejadian. Malang: Gandum Mas.

Keil and Kelitzsch. 1953. Biblical Commentary, jilid 1. Nashville: Broadman Press.

Kidner, Derek. 1967. Genesis. Downers Grove: InterVarsity Press.
Meyers, Eric M. 1970. "Secondary Burials in Palestine", The Biblical Archaeologist, vol. 33.

Nanda, Serena dan Richards L. Warms. 2012. Culture Counts: A Concise Introduction to Cultural Anthropology. New York:Wadsworth Cengange Learning.

Ping, Liem Thin. 2014. "Kuasa dari Tulang" dalam houseofallnations.blogspot.com. Diakses $10 / 11 / 2014$.

PUSBANG Gereja Toraja. 1992. Aluk, Adat dan Kebudayaan Toraja dalam Perjumpaan dengan Injil. Rantepao: Sulo. . Aluk Rambu Solo'. Rantepao: Sulo, 1996.

Sarungallo, Tino. 2008. Anak Toraja Kota menggugat. Yogyakarta: Tembi Rumah Budaya.

Tammu, J. dan H. van der Veen. 1972. Kamus Toradja - Indonesia. Makassar: Lembaga Bahasa Nasional Dep. P. \& K. Tjab. Makasar.

Tim Institut Theologia. 1983. Manusia Toraja: dari Mana-bagaimana-ke mana. Tangmentoe: Institut Theologia. 